\title{
The Effectiveness of Korea's Capital Flow Management System and its Implications on Exchange Rate Policy
}

\author{
Jinsoo Lee*
}

\begin{abstract}
This paper examines the effectiveness of the three macro-prudential measures introduced by the Korean government in 2010 and 2011: (i) introduction of limit for FX forward positions of domestic banks and foreign bank branches, (ii) reintroduction of tax on foreign investors' earnings from Korean government bonds, and (iii) imposition of macro-prudential stability levy on non-deposit foreign currency liabilities appeared in bank balance sheets. The results show that the three measures were not successful: The limits of FX forward position did not lead to the decrease in foreign borrowings. The reintroduction of the tax did not reduce foreign investments in Korean government bonds. Lastly, the levy on non-deposit foreign currency liabilities did not lower the foreign borrowings from the banks and did not result in more financing through deposits for banks. The ineffectiveness of the capital flow management system in controling the amount of foreign capital flows implies that the system might not be effective in mitigating the pressure on exchange rate caused by excessive volatility of foreign capital flows.
\end{abstract}

Key Words: macro-prudential measures, limit for FX forward position, tax on foreign investment in bonds, bank levy on foreign currency liabilities

JEL codes: F31, F32, F38

\footnotetext{
* Associate Professor, KDI School of Public Policy and Management.

Corresponding Address: 85 Hoegiro, Dongdaemun-Gu, Seoul, 130-722, Korea(ROK).

Tel: 822-3299-1060. Fax: 822-968-5072. Email: jlee@kdischool.ac.kr
} 


\section{Introduction}

If foreign capital flows are freely made with capital liberalization, sudden decrease or large outflow of foreign capitals can have significant impact on national economy. For example, according to Becker, Jeanne, Mauro, Ostry, and Ranciere (2007), the negative impact of the shock caused by the sudden stop of foreign capital inflows were found to be the most significant shock out of the financial and macroeconomic shocks that may cause the reduction in income in emerging markets ${ }^{1)}$ where capital markets are relatively open.

As there have been more cases where a country's economy is negatively affected by excessive volatility of capital flows during the recent global financial and economic crisis, the IMF has expressed its position that capital flow management (CFM)2) may be used as a policy measure to respond to the volatility of excessive capital flows.3) For example, according to Ostry, Ghosh, Habermeier, Chamon, Qureshi, and Reinhart (2010), policy making authorities may adopt sterilization policy, low interest rate policy or austerity policy for the purpose of allowing national currency appreciation, accumulating foreign exchange reserve, and mitigating the inflationary pressure as the macroeconomic policy measures as a response to large capital inflows, and, at the same time, they may strengthen the rules of macro-prudential measures as policy means to mitigate the risk caused by excessive borrowings from abroad. Also, it is said that if the economic situation does not allow these macro-economic means and macro-prudential regulations to be implemented or their effectiveness cannot be fully obtained, direct control over capital inflows can be adopted.4)

Based on these international discussions, the Korean government announced the mitigation plan for the excessive volatility of capital flows in June 2010 under the recognition that the root causes of the financial and foreign currency crisis that Korean economy experienced so far were due to the fact that the volatility of capital flows was excessively high5), and then introduced (i) the forward exchange position limit for foreign

1) Becker et. al (2007) defined developing countries issuing bonds in the international financial markets as emerging markets.

2) According to the IMF, capital flow management (CFM) includes (i) capital controls that discriminate between residents and non-residents and (ii) capital flow management that does not discriminate between residents and non-residents. (IMF (2012a)).

3) Regarding the IMF's position that capital flow management can be uses as a policy measure to respond to the excessive volatility of capital flows, refer to the IMF (2011, 2012a, 2012b), Ostry, Ghosh, Habermeier, Chamon, Qureshi, Reinhardt (2010), Ostry, Ghosh, Habermeier, Chamon, Qureshi and Kokenyne (2011).

4) Jang(2013) also suggests that "the precautionary and effective policies such as prudential regulations on the short-term capital transactions are strongly needed to emerging markets in order to prevent the excessive fluctuations in the financial markets over the macroeconomic fundamentals." 
exchange banks, (ii) the abolition of non-taxation on the interest income for foreign investment in bonds, and (iii) the bank levy for non-deposit foreign currency liabilities of foreign exchange banks.

This paper intends to investigate the effects of the introduction of these three systems and their implication on exchange rate policy. This paper is composed as follows. In Section 2, the background of the Korean government's introduction of the 'mitigation measures for excessive volatilities in capital flows' and the three measures introduced will be described. In Section 3, the effects of the introduction of these three systems will be analyzed. In Section 4, the implication on foreign exchange policy will be discussed.

\section{Introduction of Three Capital Flow Management Measures by Korean Government}

Under the recognition that the root cause of the financial and currency crisis experienced by Korea's economy was due to excessively high volatility of capital flows, the Korean government announced the mitigation measures for excessive volatilities in capital flows in June 2010, and then introduced the cash flow management measures including (i) the forward exchange position limit fort foreign exchange banks, (ii) the abolition of non-taxation on the interest income for the foreign investment in bonds, and (iii) the imposition of bank levy on bank's non-deposit foreign currency liabilities.

The forward exchange position limit for foreign exchange banks was introduced for the purpose of reducing foreign borrowings, in particular, short-term borrowings by foreign exchange banks. The abolition of non-taxation on the interest income for the foreigners' investment in bonds was introduced for the purpose of mitigating the volatility in the foreign investment in securities by reducing the incentives for foreign investment in domestic bonds. The bank levy on the foreign exchange banks' non-deposit foreign currency liabilities was introduced for the purposes of reducing the scale of non-deposit foreign currency liabilities, prolonged maturities of debts, and increase in the foreign currency deposits. The content of these three measures will be described in detail as below.

\subsection{Forward Exchange Position Limit for Foreign Exchange Banks}

The forward exchange position limit system for foreign exchange banks was

5) Press release dated June 132010 by the Ministry of Strategy and Finance, the Bank of Korea, and the Financial Supervisory Service. 
introduced for the purpose of reducing the scale of foreign borrowings, in particular, short-term borrowings by foreign exchange banks.

Korean shipbuilders or asset management companies conduct forward contracts where they sell foreign currency and buy Korean Won in the future (maturities) in order to hedge the exchange rate risks for their foreign proceeds which will be received in the future. As counterparts to the forward contracts, foreign exchange banks buy the foreign currency and sell Korean Won at maturity. In order to hedge the exchange rate risks due to the forward contracts, foreign exchange banks may borrow foreign currency and enter into spot contracts to sell the same foreign currency and buy Korean Won. In this way, the overall foreign exchange position that includes both spot exchange position and forward exchange position of foreign exchange banks is balanced and foreign exchange banks can avoid the exchange rate risk as they repay the principal and interest of foreign currency they borrowed by using the foreign currency received at maturity.

However, the excessive short-term borrowings may act as a burden on entire national economy because the short-term loans may be repaid in a short period of time when national economy is under pressure.6) Thus, the forward exchange limit for foreign exchange was introduced in October 2010. The forward exchange limit was set at $50 \%$ of the equity capital as of the end of the previous month for domestic banks and $250 \%$ for foreign banks' branches. These forward position limit decreased to $40 \%$ of the equity capital for domestic banks and 200\% for foreign banks' branches in July 2011, and they further decreased to $30 \%$ of the equity capital for domestic banks and $150 \%$ for foreign banks' branches in January 2013.

\subsection{Taxation on Foreign Investment in Bonds}

In May 2009, as one of the measures to provide more foreign currency liquidity during the financial crisis, the Korean government introduced a system that waived the withholding of corporate tax and income tax for interest income gained from the non-residents' investment in the Korean government bonds and monetary stabilization bonds and did not impose tax on the capital gains.7)

However, the Korean government has abolished this non-taxation measure in January

6) The Korean government estimated that approximately half of 195.3 billion US dollars which was the increase in the foreign debt between 2006 and 2007 was due to the purchases of forward exchange by domestic banks and the foreign banks' branches. Press release dated June 132010 by the Ministry of Strategy and Finance, the Bank of Korea and the Financial Supervisory Service.

7) Press release dated February 26, 2009 by the Ministry of Strategy and Finance, the Bank of Korea and the Financial Supervisory Service. 
2011 because of the possibility that Korean financial and foreign exchange markets are negatively affected when the non-residents' funds invested in bonds flow out within a short period time. Thus, the Korean government reintroduce taxes on foreign investment in the Korean government bonds and monetary stabilization bonds. The Korean government imposed the interest income tax (14\%) and capital gains tax (20\%) for foreign investors, the same as for domestic investors.

\subsection{Bank Levy on Non-deposit Foreign Currency Liabilities}

In August 2011, the Korean government introduced a bank levy system on the balance of the non-deposit foreign currency liabilities by foreign banks in order to reduce banks' foreign currency liabilities. ${ }^{8)}$ The rates for the bank levy on foreign currency liabilities were determined based on their maturities; $0.2 \%$ for the maturities shorter than one year. $0.1 \%$ for the maturities between one and three years, $0.05 \%$ for the maturities between three and five years, and $0.02 \%$ for the maturities over five years.

The decrease in non-deposit foreign currency liabilities and increase in foreign currency deposits were expected because the bank levy was imposed only on non-deposit foreign currency liabilities, and the maturities of non-deposit foreign currency liabilities were expected to be longer because lower rate was imposed for foreign currency liabilities with longer maturities.

\section{The Effects of Introduction of Korea's Capital Flow Management System}

This section aims to analyze the effects of introduction of the three capital flow management systems recently adopted by the Korean government including (i) the forward exchange position limit for foreign exchange banks, (ii) the abolition of non-taxation on the interest income for foreign investment in bonds, and (iii) the bank levy on the non-deposit foreign currency liabilities of foreign exchange banks. In this section, I will review factors that determine the scale of capital flows and examine whether the capital flow management systems might have an effect on capital flows.

8) The Bank of Korea implements the bank levy for foreign currency prudential regulation on foreign currency liabilities from August 1, 2011, and has established triple response system for the management of capital flows volatility. Press release dated August 1, 2011. 


\subsection{How to Measure Capital Flows}

In order to analyze the effects of the introduction of the capital flow management systems that were recently introduced, I examine whether there was increase or decrease in the balance of payments since the introduction of the systems.

In case of the forward exchange position limit for foreign exchange banks, I examine changes in (i) the borrowings by depository institutions and (ii) the borrowings by depository institutions and other institutions separately before and after October 2010 when the limit was introduced. In addition, I will study whether there was any change in (i) the short-term and long-term borrowings by depository institutions and other institutions.

In case of the abolition of non-taxation on the interest income for foreign investment in bonds, I investigate whether there was any change in foreign investment in debt securities and their composition between long-term and short-term securities before and after January 2011, when the taxation for foreign investment in bonds was reintroduced.

In case of the bank levy on the non-deposit foreign currency liabilities of foreign exchange banks, I examine whether there was any change in total borrowings, short-term and long-term borrowings, cash and deposits before and after August 2011, when the bank levy was introduced.

Each corresponding item in the monthly balance of payments is divided by monthly Korean GDP denominated in US dollar. The monthly Korean GDP is obtained by calculating the arithmetic mean of the quarterly GDP in tems of Korean Won and the monthly GDP denominated in Korean Won is divided by monthly average Korean Won/dollar exchange rate in order to have the monthly GDP denominated in US dollar. The data on the balance of payments and GDP are obtained from the Economic Statistics System of the Bank of Korea.

\subsection{Factors Related to Capital Flows}

The factors affecting a country's capital flows can be divided into (i) push factors acting from outside the country and (ii) pull factors acting in the country. The push factors determine the global liquidity conditions which are outside of control of the country, and the pull factors reflect investment opportunities for the country. ${ }^{9)}$

For the push factors, Baba and Kokenyne (2011) used he US interest rate, the difference between the actual GDP of the US and its estimated GDP by the trend, which

9) Ghosh, Kim, Qureshi, and Zalduendo(2012) 
represents the business cycle of the US economy, ${ }^{10}$ ) and global spread of JP Morgant's emerging markets bond index (EMBI) or the volatility index (VIX) of the Chicago Board Options Exchange (CBOE) as indicator of global risk appetite. Ghosh, Kim, Qureshi, and Zalduendo (2012) used the US interest rate, VIX of the Chicago Board Options Exchange and index of international commodity price.

For pull factors, Baba and Kokenyne (2011) used domestic interest rate, the difference between the forward exchange rate with three-month maturities and spot exchange rate as indicator of thee expected change in exchange rate, the difference between the actual GDP of the country and its estimated GDP by the trend, which represents the business cycle of the country, the composite risk ratings of the International Country Risk Guide (ICRG) ${ }^{11}$ ) as indicator of country risk, and the scale of current account deficit as indicator of required amount of borrowings from outside the country. Ghosh, Kim, Qureshi, and Zalduendo (2012) used domestic interest rate, the actual difference between the real effective exchange rate and its estimated one as a proxy for the overvaluation of the domestic currency, the proportion of developed countries with banks that have outstanding loans in the relevant country as indicator of the international financial connectedness of the country, and the current account deficit of the country.

This paper use the push factors acting from outside Korea and the pull factors acting from inside Korea as follows:

For the push factors, the US CD yields (90-day maturities), the difference between the US actual industrial production index and estimated industrial production index ${ }^{12)}$ as indicator of the US business cycle, and the VIX of the CBOE as indicator of international investment risk. For the pull factors, the Korean CD yields (91-day maturities), the ratio computed as the difference between 3-month maturity won/dollar forward exchange rate and spot exchange rate against spot exchange rate as indicator of the expected change in exchange rate in the market, the difference between Korea's actual industrial production index and estimated industrial production index ${ }^{13)}$ as indicator of the Korean business cycle, and the composite risk ratings of the ICRG as indicator of national risk.

The data are all monthly data. The VIX of the CBOE and three-month maturity won/dollar forward exchange rate are obtained from Datastream. The data on the composite

10) Baba and Kokenyne (2011) defined the positive (+) difference between actual GDP and estimated GDP as an economic boom.

11) The composite risk ratings of the ICRG is an index which assesses the political, economic, and financial risks of a country.

12) The estimated industrial production index of the US is computed by applying the Horick-Prescott filter to the actual industrial production index from January 2000 to July 2012. The smoothing factor is 14,400 .

13) The estimated industrial production index of Korea is computed by applying the Horick-Prescott filter to the actual industrial production index from January 2000 to July 2012. The smoothing factor is 14,400. 
risk ratings of the ICRG are from the PRS Group. Other data are from the Economic Statistics System of the Bank of Korea.

\subsection{Analysis of the Introduction Effects of Capital Flow Management System}

Since the records of the financial account transactions in the balance of payments for each of the subjects such as the general government, central bank, depository institutions, and other sectors have been recorded since January 2003, my analysis starts from January 2003 and ends in July 2012.

\section{A. Effectiveness of the Introduction of Forward Exchange Position Limit System for Foreign Exchange Banks}

I examine the effects of the introduction of forward exchange position limit system on the capital inflows after controlling other factors that may affect capital inflows discussed earlier with a regression analysis where the dependent variable is the amount of the capital inflows into Korea due to borrowings between January 2003 and September 2010. For independent variables, the push and pull factors explained earlier and the period dummy variables representing the period from January 2010 to July 2012, when the forward exchange position limit system was introduced, are used. (<Table 1>) For the depository institutions and private sector, the coefficients of the period dummy variable are -0.81 and 0.77 , respectively. However, neither of the coefficients are statistically significant. The results suggest that the introduction of forward exchange position limit system did not lead to the decrease in the borrowings by the depository institutions and private sector.

\section{Table 1.}

Results of the Regression Analysis for Borrowings (in percent of GDP) due to the Introduction of Forward Exchange Position Limit

(Sample Period: January 2003 July 2012)

\begin{tabular}{|c|c|c|}
\hline \multirow[t]{2}{*}{ Dependent Variable } & \multicolumn{2}{|c|}{$\begin{array}{l}\text { Capital Inflows due to Borrowings } \\
\text { (in percent of GDP) }\end{array}$} \\
\hline & Depository Institutions & Private Sector \\
\hline Constant & $\begin{array}{c}74.31^{* *} \\
(3.45) \\
\end{array}$ & $\begin{array}{c}76.89^{* *} \\
(3.57) \\
\end{array}$ \\
\hline
\end{tabular}




\begin{tabular}{|c|c|c|}
\hline \multirow[t]{2}{*}{ Dependent Variable } & \multicolumn{2}{|c|}{$\begin{array}{l}\text { Capital Inflows due to Borrowings } \\
\text { (in percent of GDP) }\end{array}$} \\
\hline & Depository Institutions & Private Sector \\
\hline Korea's CD rate & $\begin{array}{l}-2.75^{*} \\
(-2.40)\end{array}$ & $\begin{array}{l}-2.74 * \\
(-2.44)\end{array}$ \\
\hline The US CD rate & $\begin{array}{l}2.84 * * \\
(3.23)\end{array}$ & $\begin{array}{l}2.77^{* *} \\
(3.22)\end{array}$ \\
\hline $\begin{array}{c}\text { Forward exchange rate premium / } \\
\text { spot exchange rate }\end{array}$ & $\begin{array}{l}8.52 * * \\
(3.25)\end{array}$ & $\begin{array}{l}8.13 * * \\
(3.20)\end{array}$ \\
\hline $\begin{array}{c}\text { Korea's business cycle } \\
\text { (industrial production index) }\end{array}$ & $\begin{array}{l}0.39^{*} \\
(2.17)\end{array}$ & $\begin{array}{l}0.40^{*} \\
(2.31)\end{array}$ \\
\hline $\begin{array}{l}\text { The US business cycle } \\
\text { (industrial production index) }\end{array}$ & $\begin{array}{l}-0.03 \\
(-0.05) \\
\end{array}$ & $\begin{array}{c}0.03 \\
(0.06) \\
\end{array}$ \\
\hline Korea's country risk (ICRG) & $\begin{array}{c}-0.87 * * \\
(-3.25) \\
\end{array}$ & $\begin{array}{l}-0.90 * * \\
(-3.35) \\
\end{array}$ \\
\hline $\begin{array}{l}\text { Balance on current account } \\
\text { (in percent of GDP) }\end{array}$ & $\begin{array}{l}-0.50^{*} \\
(-2.40) \\
\end{array}$ & $\begin{array}{l}-0.50 * \\
(-2.45) \\
\end{array}$ \\
\hline VIX of the CBOE & $\begin{array}{c}-0.01 \\
(-0.06)\end{array}$ & $\begin{array}{c}0.01 \\
(0.01)\end{array}$ \\
\hline $\begin{array}{c}\text { Period dummy variable } \\
\text { (October 2010 July 2012) }\end{array}$ & $\begin{array}{c}-0.81 \\
(-0.48) \\
\end{array}$ & $\begin{array}{c}-0.77 \\
(-0.46) \\
\end{array}$ \\
\hline Sample size (N) & 115 & 115 \\
\hline F statistic & $5.30^{* *}$ & $5.32 * *$ \\
\hline $\mathrm{R}^{2}$ & 0.458 & 0.453 \\
\hline
\end{tabular}

Note: 1$) * *$ and $*$ denote the statistical significance at the level of $1 \%$ and $5 \%$, respectively.

2) The private sector is composed of depository institutions and other sectors.

3) Figures shown in brackets are the heteroscedasticity-robust t-statistics.

Next, I examine the effect of the introduction of forward exchange position limit system on the short-term borrowings by depository institutions and private sector. Table 2 reports the results of a regression analysis for the depository institutions and private sector to investigate the effects of the introduction of forward exchange position limit system on the short-term borrowings after controlling the push and pull factors that may affect the capital inflows. The coefficients of period dummy variables are -1.43 and -1.42 , respectively, but neither of the coefficients are statistically significant. The results indicate that the introduction of forward exchange position limit system did not lead to the decrease in the short-term borrowings by the depository institutions and private sector. 


\section{Table 2.}

Results of the Regression Analysis for Short-term Borrowings (in percent of GDP) due to the Introduction of Forward Exchange Position Limit

(Sample Period: January $2003 \sim$ July 2012)

\begin{tabular}{|c|c|c|}
\hline \multirow[t]{2}{*}{ Dependent Variable } & \multicolumn{2}{|c|}{$\begin{array}{l}\text { Capital Inflows due to Short-term Borrowings } \\
\text { (in percent of GDP) }\end{array}$} \\
\hline & Depository Institutions & Private Sector \\
\hline Constant & $\begin{array}{c}60.53^{* *} \\
(2.97)\end{array}$ & $\begin{array}{c}59.99 * * \\
(2.95)\end{array}$ \\
\hline Korea's CD rate & $\begin{array}{l}-2.59^{*} \\
(-2.25)\end{array}$ & $\begin{array}{l}-2.55^{*} \\
(-2.22)\end{array}$ \\
\hline The US CD rate & $\begin{array}{l}2.64 * * \\
(2.96)\end{array}$ & $\begin{array}{l}2.57^{* *} \\
(2.91)\end{array}$ \\
\hline $\begin{array}{l}\text { Forward exchange rate premium / spot } \\
\text { exchange rate }\end{array}$ & $\begin{array}{l}7.98^{* *} \\
(3.01)\end{array}$ & $\begin{array}{l}7.67^{* *} \\
(2.93)\end{array}$ \\
\hline $\begin{array}{l}\text { Korea's business cycle (industrial } \\
\text { production index) }\end{array}$ & $\begin{array}{l}0.35^{*} \\
(2.05)\end{array}$ & $\begin{array}{l}0.36^{*} \\
(2.08)\end{array}$ \\
\hline $\begin{array}{l}\text { The US business cycle (industrial } \\
\text { production index) }\end{array}$ & $\begin{array}{c}-0.09 \\
(-0.18)\end{array}$ & $\begin{array}{c}-0.10 \\
(-0.19)\end{array}$ \\
\hline Korea's country risk (ICRG) & $\begin{array}{l}-0.69^{* *} \\
(-2.69)\end{array}$ & $\begin{array}{l}-0.68 * * \\
(-2.66)\end{array}$ \\
\hline $\begin{array}{l}\text { Balance on current account } \\
\text { (in percent of GDP) }\end{array}$ & $\begin{array}{l}-0.50^{*} \\
(-2.50) \\
\end{array}$ & $\begin{array}{l}-0.52 * \\
(-2.60)\end{array}$ \\
\hline VIX of the CBOE & $\begin{array}{l}-0.05 \\
(-0.39)\end{array}$ & $\begin{array}{l}-0.05 \\
(-0.41)\end{array}$ \\
\hline $\begin{array}{l}\text { Period dummy variable } \\
\text { (October } 2010 \sim \text { July 2012) }\end{array}$ & $\begin{array}{l}-1.43 \\
(-0.86)\end{array}$ & $\begin{array}{l}-1.42 \\
(-0.85)\end{array}$ \\
\hline Sample size $(\mathrm{N})$ & 115 & 115 \\
\hline F statistic & $5.78^{* *}$ & $5.76^{* *}$ \\
\hline $\mathrm{R}^{2}$ & 0.471 & 0.466 \\
\hline
\end{tabular}

Note: 1) ** and * denote the statistical significance at the level of $1 \%$ and $5 \%$, respectively.

2) The private sector is composed of depository institutions and other sectors.

3) Figures shown in brackets are the heteroscedasticity-robust t-statistics.

Finally, I examine the effect of the introduction of forward exchange position limit system on the short-term borrowings by depository institutions and private sector. Table 3 reports the results of a regression analysis for the depository institutions and private sector to investigate the effects of the introduction of forward exchange position limit system on the long-term borrowings after controlling the push and pull factors that may affect the 
capital inflows. The coefficients of period dummy variables are 0.62 and 0.65 , respectively, and both coefficients are statistically significant at the level of $5 \%$. Thus, the results indicate that the depository institutions and private sector rather increased long-term borrowings despite of the introduction of the forward exchange position limit. Such an increase in long-term borrowings may be a result of the foreign exchange prudential management for foreign exchange banks introduced by the Korean government at the same time with the introduction of the forward exchange position limit. ${ }^{14)}$

\section{Table 3.}

Results of the Regression Analysis for Long-term Borrowings (in percent of GDP) due to the Introduction of Forward Exchange Position Limit

(Sample Period: January $2003 \sim$ July 2012)

\begin{tabular}{|c|c|c|}
\hline \multirow[t]{2}{*}{ Dependent Variable } & \multicolumn{2}{|c|}{$\begin{array}{l}\text { Capital Inflows due to Long-term Borrowings } \\
\text { (in percent of GDP) }\end{array}$} \\
\hline & Depository Institutions & Private Sector \\
\hline Constant & $\begin{array}{c}13.78 * * \\
(4.15)\end{array}$ & $\begin{array}{c}16.90 * * \\
(4.55)\end{array}$ \\
\hline Korea's CD rate & $\begin{array}{l}-0.16 \\
(-1.01)\end{array}$ & $\begin{array}{l}-0.19 \\
(-1.13)\end{array}$ \\
\hline The US CD rate & $\begin{array}{c}0.21 \\
(1.57) \\
\end{array}$ & $\begin{array}{c}0.19 \\
(1.37)\end{array}$ \\
\hline $\begin{array}{l}\text { Forward exchange rate premium / spot } \\
\text { exchange rate }\end{array}$ & $\begin{array}{c}0.53 \\
(1.25)\end{array}$ & $\begin{array}{c}0.46 \\
(1.03)\end{array}$ \\
\hline $\begin{array}{l}\text { Korea's business cycle } \\
\text { (industrial production index) }\end{array}$ & $\begin{array}{c}0.03 \\
(1.54)\end{array}$ & $\begin{array}{c}0.05 \\
(1.89)\end{array}$ \\
\hline $\begin{array}{l}\text { The US business cycle (industrial production } \\
\text { index) }\end{array}$ & $\begin{array}{c}0.07 \\
(1.06)\end{array}$ & $\begin{array}{l}0.13^{*} \\
(2.12)\end{array}$ \\
\hline Korea's country risk (ICRG) & $\begin{array}{l}-0.18 * * \\
(-4.26) \\
\end{array}$ & $\begin{array}{l}-0.22 * * \\
(-4.60)\end{array}$ \\
\hline $\begin{array}{l}\text { Balance on current account } \\
\text { (in percent of GDP) }\end{array}$ & $\begin{array}{c}0.01 \\
(0.13)\end{array}$ & $\begin{array}{c}0.02 \\
(0.74)\end{array}$ \\
\hline VIX of the CBOE & $\begin{array}{c}0.04 \\
(1.97)\end{array}$ & $\begin{array}{l}0.05^{*} \\
(2.43)\end{array}$ \\
\hline
\end{tabular}

14) The Korean government raised the long-term funding ratio (the ratio of foreign currency loans with maturities exceeding one year and the foreign currency loans with maturities over one year) of domestic banks from $90 \%$ to more than $100 \%$. Press release dated June 132010 by the Ministry of Strategy and Finance, the Bank of Korea, and the Financial Supervisory Service. 


\begin{tabular}{c|c|c}
\hline \multirow{2}{*}{ Dependent Variable } & \multicolumn{2}{c}{$\begin{array}{r}\text { Capital Inflows due to Long-term Borrowings } \\
\text { (in percent of GDP) }\end{array}$} \\
\cline { 2 - 3 } & \multicolumn{2}{|c}{$\begin{array}{c}\text { Depository Institutions } \\
\text { Private Sector }\end{array}$} \\
\hline $\begin{array}{c}0.62^{*} \\
(2.10)\end{array}$ & $\begin{array}{c}0.65^{*} \\
(2.10)\end{array}$ \\
\hline Period dummy variable (October 2010 July & 115 & 115 \\
\hline Sample size (N) & $3.69^{* *}$ & $5.65^{* *}$ \\
\hline $\mathrm{R}^{2}$ & 0.298 & 0.365 \\
\hline
\end{tabular}

Note: 1$)^{* *}$ and $*$ denote the statistical significance at the level of $1 \%$ and $5 \%$, respectively.

2) The private sector is composed of depository institutions and other sectors.

3) Figures shown in brackets are the heteroscedasticity-robust t-statistics.

\section{B. Effects of the Reintroduction of Taxation on Foreign Investment in Bonds}

I examine the capital inflows due to investment in bonds, investment in short-term bonds and investments in long-term bonds by non-residents especially for the period from May 2009 to December 2010 when the non-taxation on foreign investment in bonds was conducted and for the period from January 2011 to July 2012 when the taxation was reintroduced.

Table 4 reports the results of a regression analysis for the effects of the reintroduction of the taxation on foreign investment in bonds on the capital inflows due to non-residents' investment in bonds, long-term bonds and short-term-bonds. The coefficients of the period dummy variable for the period from January 2011 to July 2012 are $-0.70,-0.14$, and -0.56 , respectively. However, neither of them are statistically significant. The results suggest that the reintroduction of the taxation on foreign investment in bonds did not lead to the decrease in the non-residents' investment in bonds.

Table 4.

Results of Regression Analysis of Foreign Investment in Bonds (in percent of GDP)

(Sample Period: January $2003 \sim$ July 2012)

\begin{tabular}{c|c|c|c}
\hline \multirow{2}{*}{ Dependent Variable } & \multicolumn{3}{|c}{ Capital Inflows due to Foreign Investment in Bonds } \\
& \multicolumn{3}{|c}{ (in percent of GDP) } \\
\cline { 2 - 4 } & Bond & Short-term Bond & Long-term Bond \\
\hline \multirow{2}{*}{ Constant } & 33.91 & $15.08^{*}$ & 18.83 \\
& $(1.79)$ & $(2.18)$ & $(1.03)$ \\
\hline
\end{tabular}




\begin{tabular}{|c|c|c|c|}
\hline \multirow[t]{2}{*}{ Dependent Variable } & \multicolumn{3}{|c|}{$\begin{array}{l}\text { Capital Inflows due to Foreign Investment in Bonds } \\
\text { (in percent of GDP) }\end{array}$} \\
\hline & Bond & Short-term Bond & Long-term Bond \\
\hline Korea's CD rate & $\begin{array}{c}0.15 \\
(0.18)\end{array}$ & $\begin{array}{c}-0.17 \\
(-0.54)\end{array}$ & $\begin{array}{c}0.32 \\
(0.46)\end{array}$ \\
\hline The US CD rate & $\begin{array}{l}-0.86 \\
(-1.43)\end{array}$ & $\begin{array}{l}-0.06 \\
(-0.22)\end{array}$ & $\begin{array}{l}-0.80 \\
(-1.68)\end{array}$ \\
\hline $\begin{array}{c}\text { Forward exchange rate premium / } \\
\text { spot exchange rate } \\
\end{array}$ & $\begin{array}{l}-3.26 \\
(-1.57) \\
\end{array}$ & $\begin{array}{l}-0.25 \\
(-0.25)\end{array}$ & $\begin{array}{l}-3.02 * \\
(-2.02)\end{array}$ \\
\hline $\begin{array}{c}\text { Korea's business cycle } \\
\text { (industrial production index) }\end{array}$ & $\begin{array}{c}0.05 \\
(0.40) \\
\end{array}$ & $\begin{array}{c}0.01 \\
(0.25) \\
\end{array}$ & $\begin{array}{c}0.04 \\
(0.38) \\
\end{array}$ \\
\hline $\begin{array}{l}\text { The US business cycle } \\
\text { (industrial production index) }\end{array}$ & $\begin{array}{l}0.69^{*} \\
(2.06)\end{array}$ & $\begin{array}{c}0.18 \\
(1.56)\end{array}$ & $\begin{array}{c}0.51 \\
(1.81)\end{array}$ \\
\hline Korea's country risk (ICRG) & $\begin{array}{l}-0.35 \\
(-1.52) \\
\end{array}$ & $\begin{array}{l}-0.18^{* *} \\
(-2.15) \\
\end{array}$ & $\begin{array}{c}-0.17 \\
(-0.77)\end{array}$ \\
\hline $\begin{array}{l}\text { Balance on current account } \\
\text { (in percent of GDP) }\end{array}$ & $\begin{array}{c}0.13 \\
(0.90)\end{array}$ & $\begin{array}{l}-0.01 \\
(-0.16) \\
\end{array}$ & $\begin{array}{c}0.14 \\
(1.07)\end{array}$ \\
\hline VIX of the CBOE & $\begin{array}{c}-0.12 \\
(-1.80)\end{array}$ & $\begin{array}{c}0.01 \\
(0.05)\end{array}$ & $\begin{array}{l}-0.12 * \\
(-2.04)\end{array}$ \\
\hline $\begin{array}{l}\text { Period dummy variable } 1 \\
\text { (January 2003 April 2009) }\end{array}$ & $\begin{array}{c}0.54 \\
(0.26)\end{array}$ & $\begin{array}{c}0.61 \\
(0.92)\end{array}$ & $\begin{array}{l}-0.08 \\
(-0.04)\end{array}$ \\
\hline $\begin{array}{l}\text { Period dummy variable } 2 \\
\text { (January } 2011 \sim \text { July 2012) }\end{array}$ & $\begin{array}{l}-0.70 \\
(-0.45)\end{array}$ & $\begin{array}{c}-0.14 \\
(-0.30)\end{array}$ & $\begin{array}{c}-0.56 \\
(-0.44) \\
\end{array}$ \\
\hline Sample size $(\mathrm{N})$ & 115 & 115 & 115 \\
\hline F statistic & 1.75 & 0.82 & 1.80 \\
\hline $\mathrm{R}^{2}$ & 0.189 & 0.073 & 0.187 \\
\hline
\end{tabular}

Note: 1$)^{* *}$ and * denote the statistical significance at the level of $1 \%$ and $5 \%$, respectively.

2) Figures shown in brackets are the heteroscedasticity-robust t-statistics.

\section{Effectiveness of the Introduction of the Bank Levy System as Foreign Currency Prudential Regulation}

Since the bank levy for foreign currency prudential regulation was imposed only on non-deposit foreign currency liabilities, the non-deposit foreign currency liabilities could decrease, and the deposits in foreign currency could increased. In addition, the maturities of non-deposit foreign currency liabilities could be prolonged as the levy rate was lower with longer maturities. For this reason, this paper examines whether there were decrease in 
borrowings, prolonged period of borrowings, and increase in cash and deposits of depository institutions in order to study the effects of the introduction of the bank levy system as foreign exchange prudential regulation.

In order to investigate the effects of the introduction of the bank levy system as foreign currency prudential regulation on the capital inflows, a regression analysis is conducted where each of the inflows due to the loans, short-term borrowings and long-term borrowings between January 2003 and September 2010 is used as the dependent variable. The main independent variable is the period dummy variable representing the period from August 2011 to July 2012, when the bank levy system was introduced . ( $<$ Table 5>, $<$ Table $6>$ and $<$ Table $7>$ ) The results show that neither of the coefficients for the period dummy variable are statistically significant. All these results indicate that the introduction of the bank levy system did not lead to the decrease in borrowings from depository institutions or prolonged maturities of their liabilities.

\section{Table 5.}

Results of Regression Analysis of Borrowings by Depository Institutions (in percent of GDP) due to the Introduction of the Bank Levy System as Foreign Currency Prudential Regulation

(Sample Period: January 2003 July 2012)

\begin{tabular}{c|c|c}
\hline \multirow{2}{*}{ Dependent Variable } & \multicolumn{2}{|c}{$\begin{array}{c}\text { Capital Inflows due to the Borrowings by Depository } \\
\text { Institutions (in percent of GDP) }\end{array}$} \\
& $70.74^{* *}$ & $72.97^{* *}$ \\
Constant & $(3.35)$ & $(3.38)$ \\
\hline \multirow{2}{*}{ Korea's CD rate } & $-2.70^{*}$ & $-2.74^{*}$ \\
& $(-2.39)$ & $(-2.38)$ \\
\hline The US CD rate & $2.94^{* *}$ & $2.80^{* *}$ \\
& $(3.47)$ & $(3.07)$ \\
\hline Forward exchange rate premium / spot & $8.51^{* *}$ & $8.32^{* *}$ \\
exchange rate & $(3.16)$ & $(3.03)$ \\
\hline Korea's business cycle (industrial production & $0.40^{*}$ & $0.39^{*}$ \\
index) & $(2.32)$ & $(2.20)$ \\
\hline The US business cycle (industrial & -0.17 & -0.05 \\
production index) & $(-0.38)$ & $-0.09)$ \\
\hline \multirow{2}{*}{ Korea's country risk (ICRG) } & $-0.83^{* *}$ & $(-3.14)$ \\
& $(-3.06)$ & $-0.51^{*}$ \\
GDP) & $-0.51^{*}$ & $(-2.39)$ \\
\hline Balance on current account (in percent of & $(-2.39)$ & -0.01 \\
VIX of the CBOE & -0.01 & $(-0.11)$ \\
\hline
\end{tabular}




\begin{tabular}{c|c|c}
\hline Dependent Variable & $\begin{array}{r}\text { Capital Inflows due to the Borrowings by Depository } \\
\text { Institutions (in percent of GDP) }\end{array}$ \\
\hline $\begin{array}{c}\text { Period dummy variable 1 (October 2010 } \\
\text { July 2012) }\end{array}$ & $\begin{array}{c}-1.11 \\
(-0.56)\end{array}$ \\
\hline $\begin{array}{c}\text { Period dummy variable 2 (August 2011 } \\
\text { July 2012) }\end{array}$ & $\begin{array}{c}-0.02 \\
(-0.02)\end{array}$ \\
\hline Sample size (N) & 115 & $(0.34)$ \\
\hline F statistic & $5.26^{* *}$ & 415 \\
\hline $\mathrm{R}^{2}$ & 0.457 & $0.76^{* *}$ \\
\hline
\end{tabular}

Note: 1$)^{* *}$ and $*$ denote the statistical significance at the level of $1 \%$ and $5 \%$, respectively.

2) Figures shown in brackets are the heteroscedasticity-robust t-statistics.

\section{Table 6.}

Results of Regression Analysis of Short-term Borrowings by Depository Institutions (in percent of GDP) due to the Introduction of the Bank Levy System as Foreign Currency Prudential Regulation

(Sample Period: January 2003 July 2012)

\begin{tabular}{c|c|c}
\hline \multirow{2}{*}{ Dependent Variable } & \multicolumn{2}{c}{$\begin{array}{c}\text { Capital Inflows due to the Short-term Borrowings by } \\
\text { Depository Institutions (in percent of GDP) }\end{array}$} \\
\cline { 2 - 3 } Constant & $54.62^{* *}$ & $58.42^{* *}$ \\
& $(2.64)$ & $(2.83)$ \\
\hline Korea's CD rate & $-2.51^{*}$ & $-2.58^{*}$ \\
The US CD rate & $(-2.21)$ & $(-2.22)$ \\
\hline Forward exchange rate premium / spot & $2.81^{* *}$ & $2.57^{* *}$ \\
exchange rate & $(3.26)$ & $(2.79)$ \\
\hline Korea's business cycle (industrial production & $7.99^{* *}$ & $7.67^{* *}$ \\
index) & $(2.93)$ & $(2.76)$ \\
\hline index) & $0.38^{*}$ & $0.37^{*}$ \\
\hline The US business cycle (industrial production & $(2.23)$ & -0.13 \\
\hline Korea's country risk (ICRG) & -0.33 & $(-0.25)$ \\
\hline Balance on current account (in percent of & $(-0.74)$ & $-0.65^{*}$ \\
GDP) & $-0.62^{* *}$ & $(-2.51)$ \\
\hline VIX of the CBOE & $(-2.34)$ & $-0.51^{*}$ \\
& $-0.51^{*}$ & $(-2.52)$ \\
\hline July 2012) & $(-2.50)$ & -0.06 \\
& -0.05 & $-0.45)$ \\
\hline Period dummy variable 1 (October 2010 & $(-0.41)$ & -1.90 \\
& & $(-0.98)$ \\
\hline
\end{tabular}




\begin{tabular}{c|c|c}
\hline Dependent Variable & \multicolumn{2}{|c}{$\begin{array}{c}\text { Capital Inflows due to the Short-term Borrowings by } \\
\text { Depository Institutions (in percent of GDP) }\end{array}$} \\
\hline $\begin{array}{c}\text { Period dummy variable 2 (August 2011 } \\
\text { July 2012) }\end{array}$ & $\begin{array}{c}-0.13 \\
(-0.08)\end{array}$ & $\begin{array}{c}0.98 \\
(0.53)\end{array}$ \\
\hline Sample size (N) & 115 & 115 \\
\hline F statistic & $5.75^{* *}$ & $5.22^{* *}$ \\
\hline $\mathrm{R}^{2}$ & 0.467 & 0.472 \\
\hline
\end{tabular}

Note: 1$)^{* *}$ and * denote the statistical significance at the level of $1 \%$ and $5 \%$, respectively.

2) Figures shown in brackets are the heteroscedasticity-robust t-statistics.

\section{Table 7.}

Results of Regression Analysis of Long-term Borrowings by Depository Institutions (in percent of GDP) due to the Introduction of the Bank Levy System as Foreign Currency Prudential Regulation

(Sample Period: January $2003 \sim$ July 2012)

\begin{tabular}{c|c|c}
\hline \multirow{2}{*}{ Dependent Variable } & \multicolumn{2}{|c}{$\begin{array}{c}\text { Capital Inflows due to the Long-term Borrowings by } \\
\text { Depository Institutions (in percent of GDP) }\end{array}$} \\
\hline Constant & $\begin{array}{c}16.12^{* *} \\
(4.31)\end{array}$ & $\begin{array}{c}14.54^{* *} \\
(4.27)\end{array}$ \\
\hline Korea's CD rate & -0.19 & -0.16 \\
& $(-1.25)$ & $(-1.05)$ \\
\hline The US CD rate & 0.14 & 0.23 \\
& $(1.06)$ & $(1.82)$ \\
\hline Forward exchange rate premium / spot & 0.51 & 0.65 \\
exchange rate & $(1.25)$ & $(1.62)$ \\
\hline Korea's business cycle (industrial production & 0.02 & 0.03 \\
index) & $(0.98)$ & $(1.27)$ \\
\hline The US business cycle (industrial production & $0.16^{* *}$ & 0.08 \\
index) & $(2.68)$ & $-0.199^{* *}$ \\
\hline Korea's country risk (ICRG) & $-0.20^{* *}$ & $(-4.42)$ \\
\hline Balance on current account (in percent of & $(-4.32)$ & 0.01 \\
GDP) & 0.01 & $(0.33)$ \\
\hline VIX of the CBOE & $(0.30)$ & $0.04 *$ \\
July 2012) & $0.04^{*}$ & $(2.26)$ \\
\hline Period dummy variable 1 (October 2010 & $(2.18)$ & $0.79^{*}$ \\
Puly 2012) & & $(2.30)$ \\
\hline Period dummy variable 2 (August 2011 & 0.10 & -0.35 \\
& $(0.27)$ & $(-0.79)$ \\
\hline
\end{tabular}




\begin{tabular}{c|c|c}
\hline Dependent Variable & \multicolumn{2}{c}{$\begin{array}{c}\text { Capital Inflows due to the Long-term Borrowings by } \\
\text { Depository Institutions (in percent of GDP) }\end{array}$} \\
\hline Sample size (N) & 115 & 115 \\
\hline F statistic & $3.45^{* *}$ & $3.66^{* *}$ \\
\hline $\mathrm{R}^{2}$ & 0.263 & 0.305 \\
\hline
\end{tabular}

Note: 1$) * *$ and $*$ denote the statistical significance at the level of $1 \%$ and $5 \%$, respectively.

2) Figures shown in brackets are the heteroscedasticity-robust t-statistics.

Finally, this paper examines whether there was an increase in cash and deposits of the depository institutions after the introduction of the bank levy system. The result of a regression analysis shows that the coefficient of period dummy variables is not statistically significant ( $<$ Table 13>). This result suggests that the introduction of the bank levy system did not lead to the increase in cash and deposits by depository institutions

\section{Table 8.}

Results of Regression Analysis of Depository Institutions' Cash \& Deposits (in percent of GDP) due to the Introduction of the Bank Levy System as Foreign Currency Prudential Regulation

(Sample Period: January $2003 \sim$ July 2012)

\begin{tabular}{c|c}
\hline Dependent Variable & $\begin{array}{c}\text { Capital Inflows due to Cash \& Deposits of } \\
\text { Depository Institutions (in percent of GDP) }\end{array}$ \\
\hline Constant & 0.71 \\
Korea's CD rate & $0.12)$ \\
\hline The US CD rate & 0.08 \\
$(0.30)$
\end{tabular}




\begin{tabular}{c|c}
\hline Dependent Variable & $\begin{array}{c}\text { Capital Inflows due to Cash \& Deposits of } \\
\text { Depository Institutions (in percent of GDP) }\end{array}$ \\
\hline VIX of the CBOE & $\begin{array}{c}0.01 \\
(0.56)\end{array}$ \\
\hline Period dummy variable (August 2011 July & $\begin{array}{c}0.30 \\
(0.43)\end{array}$ \\
\hline Sample size (N) & 115 \\
\hline F statistic & 0.61 \\
\hline $\mathrm{R}^{2}$ & 0.047 \\
\hline
\end{tabular}

Note: 1$) * *$ and $*$ denote the statistical significance at the level of $1 \%$ and $5 \%$, respectively.

2) Figures shown in brackets are the heteroscedasticity-robust t-statistics.

\section{Implications on Foreign Exchange Policy}

Foreign Exchange Rate is determined in foreign exchange market by the demand and supply of foreign exchange. Since the capital flow management system directly intends to manage the amount of foreign exchange in the market, the system has an indirect effect on foreign exchange rate. Given the stable demand of foreign exchange, the excessive volatility of the supply of foreign exchange will result in excessive volatility of foreign exchange rate. Also, if the supply of foreign exchange is successfully reduced by the system, foreign exchange rate will tend to go up.

As shown in the previous section, the capital flow management system, which was recently introduced by the Korean government, was not effective in managing the amount of foreign exchange as intended. The ineffectiveness of the capital flow management system implies that the system might not be effective in reducing the excessive volatility of foreign exchange rate. Also, the failure to reduce the capital inflows into the foreign exchange market suggests that the foreign exchange rate might not go up.

As the first check of these conjectures, I computed the standard deviation of daily exchange rate between the Korean Won and the US dollar for the two sub-periods: (i) January 2003 to September 2010 and (ii) October 2010 to July 2012. The standard deviations for the first sub-period is $132.2 \mathrm{Won} / \mathrm{US}$ dollar, which is much smaller than that of the second sub-period ( 31.7 Won/US dollar). I also computed the average exchange rate of the two subperiods. The avearge exchange rate of the first sub-period is 1,098.3 Won/US dollar, which is a little lower than that of the second sub-period (1,122,3 Won/US dollar). Although the exchange rate for the second sub-period is higher than that of the first 
sub-period which is consistent with the conjecture, the volatility of the second period is much smaller than that of the first sub-period, which is not consistent with the conjecture. This inconsistency may arise because the demand of foreign exchange might be also volatile over these two sub-periods. This issue requires further study in the future.

\section{Conclusions}

This paper analyzes the effects of the capital flow management systems recently introduced by the Korean government including (i) the forward exchange position limit for foreign exchange banks, (ii) the abolition of non-taxation on the interest income for foreign investment in bonds, and (iii) the bank levy on the bank's non-deposit foreign currency liabilities as foreign currency prudential regulation .

The forward exchange limit system for foreign exchange banks was introduced in October 2010. The forward exchange limit was set at $50 \%$ of the equity capital as of the end of the previous month for domestic banks and $250 \%$ for foreign banks' branches. The forward exchange position limit system for foreign exchange banks was introduced for the purpose of reducing the amount of borrowings, in particular, short-term borrowings by foreign exchange banks. However, the introduction of the forward exchange limit system did not lead to the decrease in borrowings and short-term borrowings by foreign exchange banks. The long-term borrowings by the depository institutions and private sector rather increased after the introduction of the forward exchange position limit.

The tax on the interest income for the foreign investment in bonds was reintroduced in January 2011. This system was introduced for the purpose of mitigating the excessive volatility of the capital flows of foreign investment in bonds by reducing the incentives for foreign investment in Korean bonds through the taxation on the interest income. However, the analysis results of this paper suggest that the reintroduction of the taxation on foreign investment in bonds did not lead to the decrease in the non-residents' investment in bonds.

The bank levy on foreign exchange banks' non-deposit foreign currency liabilities was introduced for the purpose of the reduction in the amount of non-deposit foreign currency liabilities, prolonged maturities of debts, and increase in the foreign currency deposits. However, the analysis results of this paper show that the introduction of bank levy did not lead to the decrease in borrowings or prolonged maturities.

The ineffectiveness of the capital flow management system in controling the amount of foreign capital flows implies that the system might not be effective in mitigating the pressure on exchange rate caused by excessive volatility of foreign capital flows. 


\section{References}

Baba, C. and Kokenyne. A. (2011), "Effectiveness of Capital Controls in Selected Emerging Markets in the 2000s," IMF WP/11/281.

Becker, T., Jeanne, O., Mauro, P. and Ostry, J. (2007), "Country Insurance: The Role of Domestic Policy," IMF Occasional Paper.

Ghosh, A., J. Kim, Qureshi, M. and Zalduendo, J. (2012),"Surge," IMF WP/12/22.

International Monetary Fund (2011), "Recent Experiences in Managing Capital Inflows Cross-cutting Themes and Possible Policy Framework,".

International Monetary Fund (2012a), "Liberalizing Capital Flows and Managing Outflows,".

International Monetary Fund (2012b), "The Liberalization and Management of Capital Flows: An Institutional View,".

Ostry, J., Ghosh, A., Habermeier, K., Chamon, M., Qureshi, M. and Reinhardt, D. (2010), "Capital Inflows: The Role of Controls," IMF Staff Position Note/10/04.

Ostry, J., Ghosh, A., Habermeier, K., Chamon, M., Qureshi, M. and Kokenyne, A. (2011), "Managing Capital Inflows: What Tools to Use," IMF Staff Position Note/11/061. 